\title{
Cost and Time Analysis of the Acceleration Earthworks with the Method of Adding Heavy Equipment to the Depok-Antasari Toll Road Project
}

\author{
Irriene Indah Susanti* \& Fahmizan Rimawan \\ Faculty of Engineering, University Mercu Buana, Jakarta, Indonesia
}

\begin{abstract}
The development of Depok-Antasari Toll road construction was delayed by the work on the implementation of land work of $30.70 \%$ from the original plan presentation so that The initially planned time was completed in August 2019 extended to be completed in December 2019. In this study will analyze the acceleration of completion duration on The construction project of Depok-Antasari Toll road with an alternative to the number of heavy equipment. The purpose of this research is to know the cost of project that is physical and duration of time is faster by using the alternative. The results of the analysis was obtained that total project cost under normal conditions is IDR. 9,860,552,249.00 with the duration of project execution 130 working days. In the condition after accelerated with the addition of the number of heavy equipment alternative- 1 obtained a fee of Rp. $10,030,638,486.00$ or more expensive $1.02 \%$ of the project cost in normal conditions and duration Project execution of 109 business days or faster 21 days from the normal duration. While the total cost of the project in the alternative condition-2 obtained Rp. 10,153,918,103.00 or more expensive $1.04 \%$ of the project cost under normal conditions and duration of project execution 104 days or faster 26 days from the normal duration. It can concluded that the acceleration of work by alternative method-1 is a more effective and economical acceleration alternative, because By applying an alternate acceleration-1. The duration of project work is faster than normal circumstances and does not experience a delay of employment from the planned time of 120 days. And the total budget cost of the project is cheaper compared to the alternative acceleration method- 2 .
\end{abstract}

Keywords: Project acceleration; time and cost; adding heavy equipment.

\section{Introduction}

\subsection{Background of Study}

In the develompent of a construction project, controlling project costs is important in the process of managing project costs. In the activities of a project there will be found many problems such as wasteful use of materials, unskilled labor and the time of project completion that is not on time, causing waste of costs that are not according to plan. Planning, controlling costs and time are part of overall construction project management (Oetomo, Priyoto, \& Uhad, 2017).

Project work delays often occur due to differences in site conditions, design changes, weather effects, and errors in planning. Project delays can be anticipated by accelerating the implementation, but must pay attention to the cost factor (Santoso, 2018).

One way to speed up the duration of a project in foreign terms is crashing. The terminology of the crashing process is to reduce the duration of a job that will affect the project completion time. Crashing is a deliberate, systematic and analytic process by testing all activities in a project that are focused on activities that are on the critical path (Wulfram, 2002).

\footnotetext{
* Corresponding author.

E-mail address: irriene.shanty@gmail.com (Irriene Indah Susanti)
} 
The duration of the maximum acceleration is limited by the area of the project or work location, but there are four factors that can be optimized to carry out the acceleration of an activity that includes increasing the number of workers, scheduling overtime work, use of heavy equipment and changing construction methods in the site (Frederika, 2010).

Activities in a project vary. In this activity there are assigned resources, equipment needed, and various implementation methods that are applied so that it can be estimated the duration and cost to complete each activity (Frederika, 2010).

In section II Desari Toll Road is divided into two packages, namely section IIA which connecting Brigif-Krukut and section II B which connecting Krukut-Sawangan. Krukut-Sawangan location for earthworks at STA $10+000-12+$ 050 with a contract value of Rp. 29,129,857,100.00 experienced delays in the work of $39.70 \%$ due to problems in the land that were not ready to be worked on. In addition, at these locations demonstrations were often held by local residents because of the cost of compensation for their land that has not been reimbursed. So there is a delay for the earthwork done by PT. Lancarjaya Mandiri Abadi.

According to Ibrahim (2001) the budget plan for a building or project is the calculation of the amount of costs required for materials and wages and other costs associated with implementing the building or project.

In this study an analysis was carried out on the acceleration of earthwork by the method of adding the number of heavy equipment. Heavy equipment known in Civil Engineering is a tool used to assist humans in carrying out the work of building an infrastructure in the field of construction. Heavy equipment is an important factor in projects, especially construction projects with large scale. The purpose of these heavy equipment is to facilitate humans in doing their work so that the expected results can be achieved more easily in a relatively shorter time and hopefully the results will be better (Rostiyanti, 2002).

In this study, an analysis of plans for acceleration of earthwork on the Depok - Antasari Toll Road Section II B project for STA $10+000-12+050$ will be analyzed in an effort to meet the wishes of the Main Contractor. So for that reason the writer is interested in conducting this research with the title "Cost and Time Analysis of the Acceleration Earthworks with the Method of Adding Heavy Equipment to the Depok - Antasari Toll Road Project".

\subsection{Problem of Study}

The problem of study includes:

1. What is the total time and cost of carrying out earthworks at the Depok - Antasari Toll Road Construction Project after accelerating the work by adding the number of heavy equipment?

2. How much is the more economical cost and what is the more efficient duration of time from the acceleration of earthworks on the Depok - Antasari Toll Road Construction Project?

\subsection{Purpose of the Study}

The purpose of this study includes:

1. Knowing the total time and cost of carrying out earthworks at the Depok - Antasari Toll Road Development Project after accelerating the work by adding the number of heavy equipment.

2. Knowing the more economical cost and the more efficient duration of time from the acceleration of earthworks on the Depok - Antasari Toll Road Construction Project.

\subsection{The Scope of Study}

The scope and limitations of the problem in this study includes:

1. The research site is located in the area of Depok - Antasari Package 1 South Toll Road (Krukut -Sawangan STA $10+000-12+050$ ) only on the implementation of earthworks. 
2. The scope of the plan to accelerate work on cut to disposal, cut to fill, and Borrow Material.

3. Acceleration using the method of adding the number of heavy equipment. Where the heavy equipment used are, Excavator Backhoe, Bulldozer, Vibratory Roller, Dump Truck, and Water Tank.

4. Calculation of acceleration costs, and project duration, using Microsoft Excel software applications

\section{Methods}

To achieve the objectives of this research, the study is divided into several stages, including:

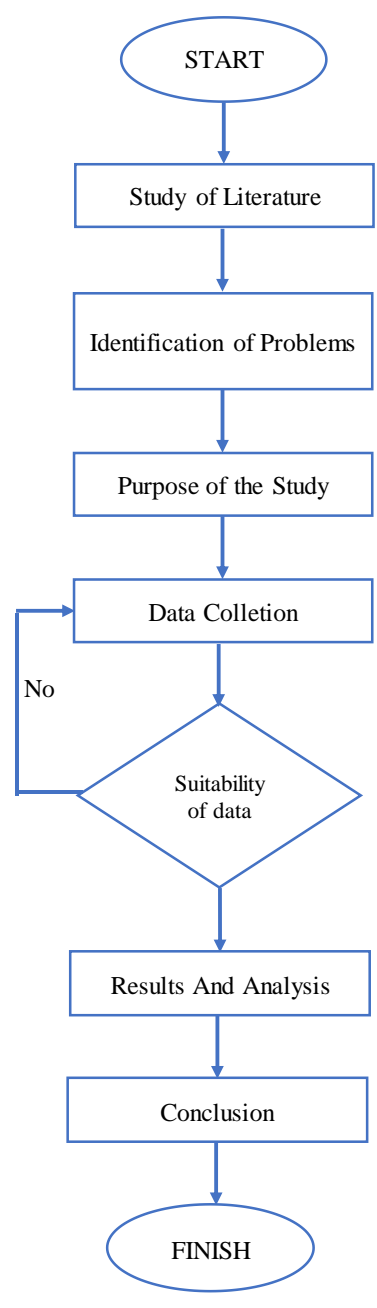

Fig. 1. Flow Diagram research Source: Data in research, 2019

The method used in this research is data collecting samples by direct observation to get a comparison of the time, and it requires a literature study by sulking on the list of unit price to get a cost comparison. 


\section{Result and Discussions}

\subsection{Project General Data}

Project data examined are as follows:

- Project

- Assignor

- Type Contract

- Main Contractor

- Sub-Contractor

- Business Hours
: Depok - Antasari Toll Road 1 South Toll Road Construction Section IIB (Krukut Sawangan) on Earthwork.

: PT. Citra Waspphutowa

: Unit Price

: PT. Girder Indonesia

: $\quad$ PT. Lancarjaya Mandiri Abadi (Sub-Con Earthwork)

: Monday - Sunday (08:00 AM - 05:00 PM)

Table 1. Volume Earthwork

\begin{tabular}{clcr}
\hline No. & \multicolumn{1}{c}{ Description } & Unit & \multicolumn{2}{l}{ Volume } \\
\hline 1 & Clearing Area & $\mathrm{m} 2$ & - \\
\hline 2 & Demolition of Houses & $\mathrm{m} 3$ & - \\
\hline 3 & Cut to Fill & $\mathrm{m} 3$ & $60.802,43$ \\
\hline 4 & Cut to Disposal & $\mathrm{m} 3$ & $16.679,70$ \\
\hline 5 & Borrow Material & $\mathrm{m} 3$ & $68.087,13$ \\
\hline
\end{tabular}

Table 2. Type and number of heavy equipment

\begin{tabular}{clccc}
\hline No & Type of Equipment & Type & Capacity & Total Units \\
\hline 1 & Bulldozer & Komatsu D68E-SS-12EO & $100-150 \mathrm{HP}$ & 1 \\
\hline 2 & Dump Truck & Hino FM260 JD & $20-30$ Ton & 6 \\
\hline 3 & Excavator & Kobelco SK 200 - 8 Sp X & $1 \mathrm{~m}^{3}$ & 2 \\
\hline 4 & Vibro Smooth & Sakai SV525DF-H & $10-12$ Ton & 1 \\
\hline 5 & Vibro Sheepfoot & Sakai SV515TF-H & $10-12$ Ton & 1 \\
\hline 6 & Water Tank Truck & Toyota Dyna & 4500 L & 1 \\
\hline
\end{tabular}

Table 3. Price of heavy equipment rental

\begin{tabular}{lllcccccccc}
\hline No & Type of Equipment & Unit & Unit Price & Fuel / Jam & $\begin{array}{c}\text { Operator Wages } \\
\text { / Jam }\end{array}$ & Total Price \\
\hline $\mathbf{a}$ & \multicolumn{1}{c}{$\mathbf{b}$} & $\mathbf{c}$ & $\mathbf{d}$ & $\mathbf{e}$ & $\mathbf{f}$ & $\mathbf{g}=\mathbf{d}+\mathbf{e}+\mathbf{f}$ \\
\hline 1 & Bulldozer & Hour & $\mathrm{Rp}$ & $275.000,00$ & $\mathrm{Rp}$ & $213.900,00$ & $\mathrm{Rp}$ & $30.000,00$ & $\mathrm{Rp}$ & $518.900,00$ \\
\hline 2 & Dump Truck & Hour & $\mathrm{Rp}$ & $135.000,00$ & $\mathrm{Rp}$ & $74.400,00$ & $\mathrm{Rp}$ & $20.000,00$ & $\mathrm{Rp}$ & $229.400,00$ \\
\hline 3 & Excavator & Hour & $\mathrm{Rp}$ & $175.000,00$ & $\mathrm{Rp}$ & $167.400,00$ & $\mathrm{Rp}$ & $25.000,00$ & $\mathrm{Rp}$ & $367.400,00$ \\
\hline 4 & Vibro Smoth & Hour & $\mathrm{Rp}$ & $155.000,00$ & $\mathrm{Rp}$ & $139.500,00$ & $\mathrm{Rp}$ & $25.000,00$ & $\mathrm{Rp}$ & $319.500,00$ \\
\hline 5 & Vibro Sheepfoot & Hour & $\mathrm{Rp}$ & $170.000,00$ & $\mathrm{Rp}$ & $139.500,00$ & $\mathrm{Rp}$ & $25.000,00$ & $\mathrm{Rp}$ & $334.500,00$ \\
\hline 6 & Water Tank Truck & Hour & $\mathrm{Rp}$ & $62.500,00$ & $\mathrm{Rp}$ & $46.500,00$ & $\mathrm{Rp}$ & $20.000,00$ & $\mathrm{Rp}$ & $129.000,00$ \\
\hline
\end{tabular}

\subsection{Analysis of Heavy Equipment Production}

Following are the results of an hourly production capacity analysis of each heavy equipment according to their work: 
Table 4. Heavy equipment production capacity

\begin{tabular}{clc}
\hline No & Type of Equipment & $\begin{array}{c}\text { Production } \\
\text { Capacity }\end{array}$ \\
\hline a & \multicolumn{1}{c}{ b } & c \\
\hline Cut to Disposal & $74,70 \mathrm{~m}^{3} /$ hour \\
\hline 1 & Excavator & $27,31 \mathrm{~m}^{3} /$ hour \\
\hline 2 & Dump Truck & \\
\hline Cut to Fill & Excavator & $74,70 \mathrm{~m}^{3} /$ hour \\
\hline 1 & Dump Truck & $27,31 \mathrm{~m}^{3} /$ hour \\
\hline 2 & Bulldozer & $132,26 \mathrm{~m}^{3} /$ hour \\
\hline 3 & Vibro Smooth & $115,16 \mathrm{~m}^{3} /$ hour \\
\hline 4 & Vibro Sheepfoot & $115,16 \mathrm{~m}^{3} /$ hour \\
\hline 5 & Water Tank Truck & $71,14 \mathrm{~m}^{3} /$ hour \\
\hline 6 & & \\
\hline Borrow & & $132,26 \mathrm{~m}^{3} /$ hour \\
\hline Material & Bulldozer & $115,16 \mathrm{~m}^{3} /$ hour \\
\hline 1 & Vibro Smooth & \\
\hline 2 & Vibro Sheepfoot & $115,16 \mathrm{~m}^{3} /$ hour \\
\hline 3 & Water Tank Truck & $71,14 \mathrm{~m}^{3} /$ hour \\
\hline 4
\end{tabular}

\subsection{Cost and Time Analysis in Normal Conditions}

\subsection{Normal Time Calculation}

Calculation of time and cost on earthworks before do acceleration using the method of adding the number of heavy equipment.

Table 5. Earthwork schedule in normal conditions

\begin{tabular}{|c|c|c|c|c|c|c|c|}
\hline \multirow[t]{2}{*}{ No. } & \multirow[t]{2}{*}{ Description } & \multirow[t]{2}{*}{ Volume $\left(\mathrm{m}^{3}\right)$} & \multirow[t]{2}{*}{$\begin{array}{c}\text { Type of } \\
\text { Equipment }\end{array}$} & $\begin{array}{l}\text { Number of } \\
\text { Heavy } \\
\text { Equipment }\end{array}$ & $\begin{array}{l}\text { Production } \\
\text { Capasity }\end{array}$ & $\begin{array}{c}\text { Productivity } \\
\text { per day }\end{array}$ & \multirow[t]{2}{*}{ Total Days } \\
\hline & & & & Unit & $\mathrm{m}^{3} /$ hour & $\mathrm{m}^{3}$ & \\
\hline \multirow{3}{*}{1} & \multirow{3}{*}{ Cut to Disposal } & \multirow{3}{*}{$16.679,70$} & Excavator & 2 & 74,70 & $1.195,20$ & \multirow{3}{*}{14} \\
\hline & & & & $r$ & & & \\
\hline & & & Dump Truck & 6 & 27,31 & $1.311,09$ & \\
\hline \multirow{7}{*}{2} & \multirow{7}{*}{ Cut to Fill } & \multirow{7}{*}{$60.802,43$} & Excavator & 2 & 74,70 & $1.195,20$ & \multirow{7}{*}{51} \\
\hline & & & Dump Truck & 6 & 27,31 & $1.311,09$ & \\
\hline & & & Bulldozer & 1 & 132,26 & $1.058,05$ & \\
\hline & & & Uibro $\mathrm{Cm}$ ch & 1 & 11516 & (201 20 & \\
\hline & & & Vidro smooth & 1 & 115,16 & $9 \angle 1,30$ & \\
\hline & & & Vibro Sheepfoo & 1 & 115,16 & 921,30 & \\
\hline & & & Water Tank & 1 & 71,14 & 569,14 & \\
\hline
\end{tabular}




\begin{tabular}{|c|c|c|c|c|c|c|c|}
\hline \multirow[t]{2}{*}{ No. } & \multirow[t]{2}{*}{ Description } & \multirow[t]{2}{*}{ Volume $\left(\mathrm{m}^{3}\right)$} & \multirow[t]{2}{*}{$\begin{array}{c}\text { Type of } \\
\text { Equipment }\end{array}$} & $\begin{array}{c}\text { Number of } \\
\text { Heavy } \\
\text { Equipment }\end{array}$ & $\begin{array}{l}\text { Production } \\
\text { Capasity }\end{array}$ & $\begin{array}{c}\text { Productivity } \\
\text { per day }\end{array}$ & \multirow[t]{2}{*}{ Total Days } \\
\hline & & & & Unit & $\mathrm{m}^{3} /$ hour & $\mathrm{m}^{3}$ & \\
\hline \multirow{4}{*}{3} & \multirow{4}{*}{ Borrow Material } & \multirow{4}{*}{$68.087,13$} & Bulldozer & 1 & 132,26 & $1.058,05$ & \multirow{4}{*}{65} \\
\hline & & & Vibro Smooth & 1 & 115,16 & 921,30 & \\
\hline & & & Vibro Sheepfoo & 1 & 115,16 & 921,30 & \\
\hline & & & Water Tank & 1 & 71,14 & 569,14 & \\
\hline
\end{tabular}

\subsubsection{Normal Cost Calculation}

The following is a recapitulation of costs for earthworks on the Depok - Antasari Toll Road project, shown in Table 6.

Table 6. Cost Recapitulation in Normal Conditions

\begin{tabular}{|c|c|c|c|c|}
\hline No & Description & & Total Cost & Percent \\
\hline 1 & Material & $\mathrm{Rp}$ & 5.752 .500 .000 & $62,60 \%$ \\
\hline 2 & Man Power & $\mathrm{Rp}$ & 666.166 .667 & $7,25 \%$ \\
\hline 3 & Heavy Equipment & $\mathrm{Rp}$ & 2.305.987.200 & $25,09 \%$ \\
\hline 4 & Mobilization and Demobilization & $\mathrm{Rp}$ & 70.000 .000 & $0,76 \%$ \\
\hline \multirow[t]{5}{*}{5} & Overhead Project & $\mathrm{Rp}$ & 395.050 .000 & $4,30 \%$ \\
\hline & Total Cost & $\mathbf{R p}$ & 9.189.703.867 & $100 \%$ \\
\hline & Interest Fees ( SCF ) (4,3\%) & $\mathrm{Rp}$ & 395.157 .266 & \\
\hline & Tax PPh (3\%) & $\mathrm{Rp}$ & 275.691.116 & \\
\hline & Total Cost & $\mathbf{R p}$ & 9.860 .552 .249 & \\
\hline
\end{tabular}

\subsection{Cost and Time Analysis on Alternative Acceleration-1}

\subsubsection{Calculation of Alternative Acceleration Times-1}

In the alternative acceleration analysis-1 is done by increasing the number of heavy equipment in the work of Excavation for Disposal and Excavation for Stockpiled, that is on Excavator, Dump Truck, Bulldozer, Vibro Smooth and Vibro Sheepfoot. 
Susanti, et.al| Quantitative Economics and Management Studies (QEMS), 2021, 2(6): 345-354

Table 7. Earthwork Schedule On Acceleration Alternative-1

\begin{tabular}{|c|c|c|c|c|c|c|c|}
\hline \multirow[t]{2}{*}{ No. } & \multirow[t]{2}{*}{ Description } & \multirow[t]{2}{*}{ Volume $\left(\mathrm{m}^{3}\right)$} & \multirow[t]{2}{*}{$\begin{array}{l}\text { Type of } \\
\text { Equipment }\end{array}$} & $\begin{array}{l}\text { Number of } \\
\text { Heavy } \\
\text { Equipment }\end{array}$ & $\begin{array}{l}\text { Production } \\
\text { Capasity }\end{array}$ & $\begin{array}{l}\text { Productivity } \\
\text { per day }\end{array}$ & \multirow[t]{2}{*}{ Total Days } \\
\hline & & & & Unit & $\mathrm{m}^{3} /$ hour & $\mathrm{m}^{3}$ & \\
\hline \multirow[b]{2}{*}{1} & \multirow{2}{*}{ Cut to Disposal } & \multirow{2}{*}{$16.679,70$} & Excavator & 3 & 74,70 & $1.792,80$ & \multirow[b]{2}{*}{10} \\
\hline & & & Dump Truck & 9 & 27,31 & $1.966,64$ & \\
\hline \multirow{7}{*}{2} & \multirow{7}{*}{ Cut to Fill } & \multirow{7}{*}{$60.802,43$} & Excavator & 3 & 74,70 & $1.792,80$ & \multirow{7}{*}{34} \\
\hline & & & Dump Truck & 9 & 27,31 & $1.966,64$ & \\
\hline & & & Bulldozer & 2 & 132,26 & $2.116,09$ & \\
\hline & & & & & & & \\
\hline & & & Vibro Smooth & 2 & 115,16 & $1.842,60$ & \\
\hline & & & Vibro Sheepfoo & 2 & 115,16 & $1.842,60$ & \\
\hline & & & Water Tank & 2 & 71,14 & $1.138,29$ & \\
\hline \multirow{4}{*}{3} & \multirow{4}{*}{ Borrow Material } & \multirow{4}{*}{$68.087,13$} & Bulldozer & 1 & 132,26 & $1.058,05$ & \multirow{4}{*}{65} \\
\hline & & & Vibro Smooth & 1 & 115,16 & 921,30 & \\
\hline & & & Vibro Sheepfoo & 1 & 115,16 & 921,30 & \\
\hline & & & Water Tank & 1 & 71,14 & 569,14 & \\
\hline
\end{tabular}

\subsubsection{Calculation of Alternative Acceleration Cost-1}

Following is the Recapitulation of the cost of accelerating work by adding the number of alternative heavy equipment - 1 for earthwork on the Depok - Antasari Toll Road project, shown in Table 8.

Table 8. Cost Recapitulation on Acceleration Alternative-1

\begin{tabular}{|c|c|c|c|c|}
\hline No & Description & & Total Cost & Percent \\
\hline 1 & Material & $\mathrm{Rp}$ & 5.752 .500 .000 & $61,54 \%$ \\
\hline 2 & Man Power & $\mathrm{Rp}$ & 631.583 .333 & $6,76 \%$ \\
\hline 3 & Heavy Equipment & $\mathrm{Rp}$ & 2.499 .935 .200 & $26,74 \%$ \\
\hline 4 & Mobilization and Demobilization & $\mathrm{Rp}$ & 110.000 .000 & $1,18 \%$ \\
\hline \multirow[t]{5}{*}{5} & Overhead Project & $\mathrm{Rp}$ & 354.200 .000 & $3,79 \%$ \\
\hline & Total Cost & $\mathbf{R p}$ & 9.348.218.533 & $100 \%$ \\
\hline & Interest Fees ( SCF ) $(4,3 \%)$ & $\mathrm{Rp}$ & 401.973 .397 & \\
\hline & Tax PPh $(3 \%)$ & $\mathrm{Rp}$ & 280.446 .556 & \\
\hline & Total Cost & $\mathbf{R p}$ & 10.030.638.486 & \\
\hline
\end{tabular}




\subsection{Cost and Time Analysis on Alternative Acceleration-2}

\subsubsection{Calculation of Alternative Acceleration Times-2}

In the alternative acceleration analysis- 2 is done by adding the number of heavy equipment in the work of excavation for dumping and landfill (Borrow Material), namely the Excavator, Dump Truck, Bulldozer, Vibro Smooth and Vibro Sheepfoot.

Table 9. Earthwork Schedule On Acceleration Alternative-2

\begin{tabular}{|c|c|c|c|c|c|c|c|}
\hline \multirow[t]{2}{*}{ No. } & \multirow[t]{2}{*}{ Description } & \multirow[t]{2}{*}{$\begin{array}{c}\text { Volume } \\
\left(\mathrm{m}^{3}\right)\end{array}$} & \multirow[t]{2}{*}{$\begin{array}{c}\text { Type of } \\
\text { Equipment }\end{array}$} & $\begin{array}{c}\text { Number of } \\
\text { Heavy } \\
\text { Equipment }\end{array}$ & $\begin{array}{c}\text { Production } \\
\text { Capasity }\end{array}$ & $\begin{array}{l}\text { Productivity } \\
\text { per day }\end{array}$ & \multirow[t]{2}{*}{ Total Days } \\
\hline & & & & Unit & $\mathrm{m}^{3} /$ hour & $\mathrm{m}^{3}$ & \\
\hline \multirow{2}{*}{1} & \multirow{2}{*}{ Cut to Disposal } & \multirow{2}{*}{$16.679,70$} & Excavator & 3 & 74,70 & $1.792,80$ & \multirow{2}{*}{10} \\
\hline & & & Dump Truck & 9 & 27,31 & $1.966,64$ & \\
\hline \multirow{6}{*}{2} & \multirow{6}{*}{ Cut to Fill } & \multirow{6}{*}{$60.802,43$} & Excavator & 2 & 74,70 & $1.195,20$ & \multirow{6}{*}{51} \\
\hline & & & Dump Truck & 6 & 27,31 & $1.311,09$ & \\
\hline & & & Bulldozer & 1 & 132,26 & $1.058,05$ & \\
\hline & & & Vibro Smooth & 1 & 115,16 & 921,30 & \\
\hline & & & Vibro Sheepfoot & 1 & 115,16 & 921,30 & \\
\hline & & & Water Tank & 1 & 71,14 & 569,14 & \\
\hline & \multirow{4}{*}{ Borrow Material } & \multirow{4}{*}{$68.087,13$} & Bulldozer & 2 & 132,26 & $2.116,09$ & \multirow{4}{*}{43} \\
\hline & & & Vibro Smooth & 2 & 115,16 & $1.842,60$ & \\
\hline & & & Vibro Sheepfool & 2 & 115,16 & $1.842,60$ & \\
\hline & & & Water Tank & 2 & 71,14 & $1.138,29$ & \\
\hline
\end{tabular}

\subsubsection{Calculation of Alternative Acceleration Cost-2}

The following is a summary of the cost of accelerating work by adding the number of alternative heavy equipment-2 for earthwork on the Depok - Antasari Toll Road project, shown in Table 10.

Table 10. Cost Recapitulation on Acceleration Alternative-2

\begin{tabular}{clrrr}
\hline No & \multicolumn{1}{c}{ Description } & & \multicolumn{1}{c}{ Total Cost } & \multicolumn{1}{c}{ Percent } \\
\hline 1 & Material & $\mathrm{Rp}$ & 5.762 .000 .000 & $60,89 \%$ \\
\hline 2 & Man Power & $\mathrm{Rp}$ & 675.875 .000 & $7,14 \%$ \\
\hline 3 & Heavy Equipment & $\mathrm{Rp}$ & 2.558 .036 .000 & $27,03 \%$ \\
\hline \multirow{2}{*}{4} & $\begin{array}{l}\text { Mobilization and } \\
\text { Demobilization }\end{array}$ & $\mathrm{Rp}$ & 113.000 .000 & $1,19 \%$ \\
\hline 5 & Overhead Project & $\mathrm{Rp}$ & 354.200 .000 & $3,74 \%$ \\
\hline & Total Cost & Rp & $\mathbf{9 . 4 6 3 . 1 1 1 . 0 0 0}$ & $\mathbf{1 0 0 \%}$ \\
\hline
\end{tabular}




\begin{tabular}{ccccc}
\hline No & Description & & Total Cost & Percent \\
\hline & Interest Fees ( SCF $)(4,3 \%)$ & $\mathrm{Rp}$ & 406.913 .773 & \\
\hline Tax PPh $(3 \%)$ & $\mathrm{Rp}$ & 283.893 .330 & \\
\hline Total Cost & Rp & $\mathbf{1 0 . 1 5 3 . 9 1 8 . 1 0 3}$ & \\
\hline
\end{tabular}

Source: Data in research, 2019

\subsection{Discussion}

The following table summarizes the comparison of the duration and cost between the duration of the project under normal conditions and the duration of the project which has been accelerated with an alternative to the addition of the number of heavy equipment.

Table 11. Cost and Time Recapitulation

\begin{tabular}{|c|c|c|c|c|c|c|c|c|c|c|c|}
\hline \multirow{2}{*}{ No } & \multirow{2}{*}{ Description } & \multirow{2}{*}{$\begin{array}{l}\text { Type of } \\
\text { Equipment }\end{array}$} & \multicolumn{3}{|c|}{ Normal Condition } & \multicolumn{3}{|c|}{ Alternative Acceleration-1 } & \multicolumn{3}{|c|}{ Alternative Acceleration-2 } \\
\hline & & & Total Units & Time & Cost & Total Units & Time & Cost & Total Units & Time & Cost \\
\hline \multirow{2}{*}{1} & \multirow{2}{*}{ Cut to Disposal } & Excavator & 2 & \multirow{12}{*}{$\begin{array}{l}10 \text { January } 2020 \\
\text { (130 Calendar Days) }\end{array}$} & \multirow{12}{*}{ Rp 9.860.552.249 } & 3 & \multirow{12}{*}{$\begin{array}{c}20 \text { December } 2019 \\
\text { (109 Calendar Days) }\end{array}$} & \multirow{12}{*}{ Rp 10.030.638.486 } & 3 & \multirow{12}{*}{$\begin{array}{c}15 \text { December } 2019 \\
\text { (104 Calendar Days) }\end{array}$} & \multirow{12}{*}{ Rp 10.153.918.103 } \\
\hline & & Dump Truck & 6 & & & 9 & & & 9 & & \\
\hline \multirow{6}{*}{2} & \multirow{6}{*}{ Cut to Fill } & Excavator & 2 & & & 3 & & & 2 & & \\
\hline & & Dump Truck & 6 & & & 9 & & & 6 & & \\
\hline & & Bulldozer & 1 & & & 2 & & & 1 & & \\
\hline & & Vibro Smooth & 1 & & & 2 & & & 1 & & \\
\hline & & Vibro Sheepfoot & 1 & & & 2 & & & 1 & & \\
\hline & & Water Tank & 1 & & & 2 & & & 1 & & \\
\hline \multirow{4}{*}{3} & \multirow{4}{*}{ Borrow Material } & Bulldozer & 1 & & & 1 & & & 2 & & \\
\hline & & Vibro Smooth & 1 & & & 1 & & & 2 & & \\
\hline & & Vibro Sheepfoot & 1 & & & 1 & & & 2 & & \\
\hline & & Water Tank & 1 & & & 1 & & & 2 & & \\
\hline
\end{tabular}

From the recapitulation of the comparison of project time and cost, it was found that in the analysis of normal conditions experienced a delay of 10 working days at a cost of Rp. 9,860,552,249. So it needs to be accelerated with the method of adding the number of heavy equipment. For alternative analysis- 1 an increase in the number of heavy equipment is carried out in Excavation for Disposal and Excavation for Stockpiling work. It turns out that the duration of the project can be accelerated to 109 days or 11 days faster than the planned time. Whereas for alternative analysis - 2 an increase in the number of heavy equipment was carried out in the work of excavation for disposal and landfill (Borrow Material), and the duration of the project could be accelerated to 104 days or 16 days earlier than planned time. However, after accelerating, it was proven that the cost had changed from Rp. 9,860,552,249, - to Rp. $10,030,638,486$, - for alternative acceleration-1 and Rp.10,153,918,103, - for alternative acceleration- 2 .

\section{Conclusions}

Based on processing data, analysis data, and discussion, several conclusions have been obtained and to answer the research objectives, as for the conclusions as follows:

1. The total project cost under normal conditions is Rp. 9,860,552,249.00 with a project duration of 130 working days. From the results of the analysis in this study, the total project cost was obtained in the aftermath of an accelerated condition with the addition of the alternative- 1 heavy equipment, which was Rp. 10,030,638,486.00 or more expensive $1.02 \%$ of the project cost under normal conditions and the duration of the project implementation 109 working days or 21 days faster than the normal duration. While the total project cost in alternative conditions- 
2 is Rp. $10,153,918,103.00$ or more expensive $1.04 \%$ of project costs under normal conditions and the duration of project implementation 104 days or 26 days faster than the normal duration.

2. In conclusion number 1 can be concluded again that the acceleration of work with the method of adding the number of heavy equipment to the alternative - 1 is an alternative acceleration that is more effective and economical, because by applying an alternative acceleration - 1 the duration of the project work is faster than normal conditions and does not experience work delays from the planned time of 120 days. And the total budget of the project cost is cheaper when compared to the alternative acceleration method - 2 . So it can be concluded that an efficient and economical acceleration is on the Alternative acceleration - 1 . Where the acceleration on the alternative - 1 adds 1 unit of heavy

\section{References}

Frederika, A. (2010). Analisis percepatan pelaksanaan dengan menambah jam kerja optimum pada proyek konstruksi. Jurnal Ilmiah Teknik Sipil, 14(2).

Ibrahim, B. (2001). Rencana dan Estimate Real of Cost. Jakarta: Bumi Aksara.

Oetomo, W., Priyoto, P., \& Uhad, U. (2017). Analisis Waktu dan Biaya dengan Metode Crash Duration pada Keterlambatan Proyek Pembangunan Jembatan Sei Hanyu Kabupaten Kapuas. Media Ilmiah Teknik Sipil, 6(1), 8-22.

Rostiyanti, S. F. (2002). Alat berat untuk proyek konstruksi. Jakarta: Rineka Cipta.

Santoso, W. (2018). Analisis Percepatan Proyek Menggunakan Metode Crashing dengan Penambahan Jam Kerja Empat Jam dan Sistem Shift Kerja (Studi Kasus: Proyek Pembangunan Gedung Animal Health Care Prof. Soeparwi, Fakultas Kedokteran Hewan UGM, Yogyakarta) (Doctoral dissertation, Universitas Islam Indonesia).

Wulfram, E. (2002). Manajemen proyek konstruksi. Yogyakarta: Andi. 